\title{
Role of TNF $\alpha$ in the etiopathogenesis of PCOS: a clinical, biochemical and molecular genetic study
}

\author{
Sujatha Thathapudi ${ }^{1 *}$, Vijayalakshmi Kodati ${ }^{1}$, Ahuja Yog Raj', Uma Addepally², Anuradha Katragadda, \\ Qurratulain Hasan ${ }^{4,5}$ \\ From International Conference on Human Genetics and 39th Annual Meeting of the Indian Society of \\ Human Genetics (ISHG) \\ Ahmadabad, India. 23-25 January 2013
}

\section{Background}

Polycystic ovarian syndrome (PCOS) is one of the most common endocrine conditions affecting women of reproductive age with a prevalence of approximately 5-10 \% worldwide. PCOS is characterized by hyperandrogenism, irregular menstrual cycles, polycystic ovaries, insulin resistance, obesity particularly abdominal phenotype. We evaluated the role of TNF $\alpha$ in PCOS patients and compared to age matched healthy controls.

\section{Methods}

204 women clinically diagnosed with PCOS and 204 healthy women controls in the age group of 17 to 35 years were evaluated. PCOS were subdiveded into Obese and lean based on BMI $\left(<25\right.$ or $\left.\leq>\geq 25 \mathrm{~kg} / \mathrm{m}^{2}\right)$. Clinical, biochemical characteristics of PCOS and molecular study of TNF alpha gene C850T polymorphism were studied.

\section{Results}

Significant differences were observed in PCOS phenotypes and controls. All the PCOS including subtypes had elevated WC, W/H, Fasting Insulin, HOMA-IR, LH, LH/ FSH, TG, and decreased HDL than Controls $(\mathrm{P}<0.0001)$. Patients had elevated serum TNF $\alpha$, Free and Total testosterone, Androstenedione and DHEA when compared to controls $(\mathrm{P}<0.05)$. We have demonstrated an association between TNF $\alpha-$ C850T polymorphism and PCOS. Frequency of $\mathrm{T}$ allele was $93.5 \%$ in PCOS and $73.5 \%$ in controls (OR 5.1863, CI 3.2893 to 8.1773 and P value $<0.0001)$. TT genotype confers a fivefold high risk for PCOS in our population (OR 5.7, CI 3.4673 to 9.3724 and $P$ value $<0.0001)$.

\footnotetext{
* Correspondence: sthathapudi@ymail.com

'Vasavi Medical Research Centre, Hyderabad, India

Full list of author information is available at the end of the article
}

\section{Conclusion}

TNF $\alpha$ contributes to the clinical, biochemical manifestations of PCOS, and -C850T TNF $\alpha$ gene polymorphism is associated with PCOS and could be used as a relevant molecular marker to identify women with risk of developing PCOS in our population.

\section{Authors' details

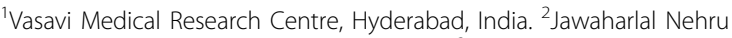 Technological University, Hyderabad, India. ${ }^{3}$ Anu Test tube baby centre, Hyderabad, India. ${ }^{4}$ Kamineni Academy of Medical Sciences and Research Centre, Hyderabad, India. ${ }^{5}$ Hyderabad Science Society, Hyderabad, India.}

Published: 21 January 2014

doi:10.1186/1755-8166-7-S1-P94

Cite this article as: Thathapudi et al: Role of TNF $\alpha$ in the etiopathogenesis of PCOS: a clinical, biochemical and molecular genetic study. Molecular Cytogenetics 2014 7(Suppl 1):P94.

Submit your next manuscript to BioMed Central and take full advantage of:

- Convenient online submission

- Thorough peer review

- No space constraints or color figure charges

- Immediate publication on acceptance

- Inclusion in PubMed, CAS, Scopus and Google Scholar

- Research which is freely available for redistribution

Submit your manuscript at www.biomedcentral.com/submit 